\title{
Quality of Work Life Evaluation among Service Sector Employees
}

\author{
Ashwini J, Dr. D. Anand \\ Research Student, Mysore University, Mysore Bahadur Institute of Management Science, University of Mysore, \\ Mysore
}

\begin{abstract}
Human capital is the main asset of the service sector companies; therefore, attrition does not just affect the headcount, but results in the loss of knowledge and skills that the employees take back with them on leaving an organisation. Quality of work life is important criteria that need to be focussed by the organisations to achieve higher productivity and business goals and retain the employees. The main objective of this study was to understand the influence of quality of work life dimensions on the overall satisfaction of the employees with the organisation Random sampling technique was used to collect opinions from 171 employees of different service sector companies. Eight quality of work life factors were examined to study the relationship with the overall satisfaction of the employees. Reliability of the data was checked using Cronbach's alpha value and the construct validity was tested using factorial analysis. Hypotheses were tested using linear regression analysis. Commitment to the organisation was considered the most important factor among the eight dimensions. Pearson's correlation analysis showed that all the factors were positively correlated to overall satisfaction. The recommendations provided in the study can be used by the organisations to rework on their policies to enhance quality of work life for employees that would have a positive impact on the attainment of business goals.
\end{abstract}

Key words: $Q W L$, service sector, commitment, job satisfaction, $Q W L$ dimensions

\section{Introduction}

To attainhigher economic status, numerous people work harder and for long durations and still struggle to get a good work life balance. Yet on day to day basis employees make conscious decision remain in the jobs which has a direct impact on their performance, job satisfaction, and coping with stress. Organisations, on the other hand, are evolving structurally, culturally, and demographically leading to high demand on multi-skilled workers who could play more than one role to meet the demanding job requirements. The service sectors especially expect their employees to perform multi-functions at challenging work environments. Notwithstanding, employees find it trying to take the burden of overloaded work which results in adverse effects in worklife, affecting directly and indirectly the personal life, mental well-being, and health. The work life stress, work life conflicts and overloaded work have a major impact on the personal and professional life of an individual [1].

The stress on service sector is much higher compared to other sectors as the competition is higher, so also the need to remain above the competition to be successful [2]. This stress gets translated to the employees who struggle to maintain the balance between the work life, family life and social life, in particular when they need to work for long hours and at times hold second jobs [3]. This study therefore focussed on quality of work life in the service sector employees to recommend suggestions that could help in altering the life style.

\section{Review of Literature}

The working environment in the service sector is filled with emotional exhaustion, stress, low levels of job satisfaction resulting in high attrition rate [4]. Ill-treating the employees and abusing them further degrades their self-esteem and self-efficacy [5]. Inefficiency of organisation to provide high quality of work life eventually results in demotivation and low performance of the employees. The employees unable to cope up with the stress in workplace tend to opt for voluntary retirement [6]. According to the researchers, the turnover intention of the employees is to a major extent is dependent on the stress in work life [7], [8]. The unfavourable conditions in the work leads to the decrease in the job satisfaction, affecting physical and mental health of the employees, thus, increasing their turnover intentions [9].

Any institution or system to endure, maintain and draw its staff members is dependent on the quality of work life it provides [10]. The important elements of a high quality work life arethe adequate and fair compensation, safe and healthy working environment, opportunity for the constant growth and development, opportunity to use the human capacities, co-operation and social integration in the work organisation, constitutionalism in the work environment, space in worklife, social relevance of work life [11].

Service industries play a crucial role in Indian economy wherein it creates employment and contributes towards national economy. Without a doubt, the postwar economy triggered a phenomenal growth in the service 
sector, which represented nearly $60 \%$ of all jobs in the United States by the end of the 1960s [12]. The work environment of the organisation dictates the ingenuity of the employees; hence, utmost attention should be given to provide a satisfying and a high quality work environment for the employees, which commensurate with other related work factors [13].

The attention to employee well-being serves as a foundation for a climate for service. Hence, the ability of the organisation to deliver higher quality service is enhanced if employees are satisfied resulting in higher performance [15]. In the case of service sector employees, quality in the work life of an employee reflects instinctively in mental and physical well-being and is appropriately conveyed as 'quality' in the service towards customers. Some studies have been conducted in the context of viewing customers as not just external entity, but the employees of the organisation are also considered internal customers [16]. A British study conducted by Holman [17] in call centres ascertains the correlation of higher levels of employee well-being with employees having greater control over work methods and procedures.

Greene, et al. [18] have demonstrated in a study that when employees are treated as internal customers and are involved in contingent organisational practices then these internal marketing resourcefulness leads to outstanding service and successful external marketing.Consequently, satisfied employees naturally provide a higher level of external service quality, furthering increased customer satisfaction [19], [20]. On the contrary, low QWL may affect the quality of services and commitment to the organisation [21].

In the service sector, the quality of work life depends on the satisfaction in a job, autonomy to prioritize the work, challenging task, motivation by the organisation and organisational commitment. Service industries are becoming increasingly important to the economies of developed nations [22]. Managers of service organisation know that their employees are the most valuable asset [23]. This is particularly relevant for those service sectors, which are largely dependent on the direct interaction of employees and customers [24]. Inducing quality into the work life of employees is an incredible task as well as inevitable for any organisation, which is especially true in the case of service sector employees. Hodson and Roscigno [25] describes that organisational success and employee well-being are complementary to each other. Any initiative taken towards improving the QWL of the employees will extend to their greater self-esteem and improved job satisfaction [26], as satisfied employees are motivated to work harder and offer better services [27]. Similarly, according to Gröpel and Kuhl [28], there is a direct relationship between satisfaction at work and social domains and work life balance and subjective well-being.

Edvardsson and Gustavsson [29] believe that despite understanding the relationship between wellbeing of the employees and success of the organisation, not much attention has been paid towards working conditions of the employees at the workplace, which is the foundation for service inclined employees. Earlier to that, Mowday et al. [30] stressed on commitment to the organisation where the employees demonstrate a strong desire to be part of the organisation, therefore, are willing to exert high level of efforts and believe and accept the goals and values of the organisation. Modern management of employees attempt to foster employee's commitment to the organisation by reinforcing employee loyalty as those committed are reported to perform better [31], [32]. In line with those thoughts, Mowday et al., [30] felt that committed employees are more aligned to the goals of the organisation and less likely to seek employment outside.

Hossain and Islam [33]claim that QWL plays a greater role in job performance than the job satisfaction. Their studies among the nurses of the government hospital demonstrated revealed a significant positive correlation between QWL and job satisfaction, between QWL and performance, and job satisfaction and performance. QWL has the highest contribution to performance.

Many of the call centres in order to compete with the service quality design tasks such that it involves the discretion of employees thereby facilitate individual autonomy [34], [35]. In contrast to this view, some companies, who aim to minimise costs and maximise volume, accentuate on service standardisation. These companies automate the tasks in such vigour that the tasks almost become "repetitive, routine and highly scripted" [35]. Acute automation of tasks strips of creative involvement of the employees' effort and offers limited job diversity and little decision-making prudence [36], [37]. Hannif [38] demonstrated that call centre employees, who were given work that had job variety and had some autonomy that helped them to control their work functions as well as working hours, were found to be a satisfied with their work, which in turn produced low turnover.

The advancing technology and easily accessible information, the study of organisations with respect to productivity, efficiency and quality of services are very crucial in order to improve the performance of work in India[39].Four dimensions have been identified as the construct of quality of nursing work life by Brook and Anderson [40] realizing the need to improve organisational productivity in the health care industry.

The relationship between job involvement, role stress and personality types were studied by Dhadda [41] in aviation and railway officials. He found a negative correlation between role overload and stress among the railway officials. On the contrary, role ambiguity had negative correlation with stress. Job involvement was also shown to be positively related to role stress. Venkatachalam et al. [42] studied the impact of job level and 
the organisation's identity on job involvement and job satisfaction among the workers of banks, schools and government organisation. In all the three organisations, job level had a significant effect on job involvement and job satisfaction and organisation's identity demonstrated an effect on job satisfaction.

Manickavasagam [43] studied the relation between morale and some factors of job performance such as productivity, labour cost, turnover, absenteeism and accidents. The study established that there are positive though insignificant relationships between morale and job performance.

In a critical study by Ramesh [44] on call centre employees exposed the vulnerabilities and insecurities of labour engaged in non-standard work. A host of insecurities to the workforce includes increased stress at work, growing attrition rates and eroding collectivity of workers. This study explained how the emergence of a new genre of worker, with distinct features and differently conceived identity, enables the firm to draw and maintain a "productively docile" workforce within a changed framework of human resource management.

Wickramasinghe [45] studied the relationship between work-related attitudes of Business Process Outsourcing (BPO) employees. Around 117 employees were selected for this study from 25 BPO firms. The two main criteria tenure and marital status were studied. Of these, tenure had an impact on task autonomy and marital status had a significant effect on working hours. The work-related attitudes of BPO employees towards their work and work environment were found to have positive correlated, which brings to the fore that these organisations provided employees with key information that could enable them to make informed managerial decisions.

In an interesting study conducted by Juliet Mary [46] among the IT and ITES employees shows that QWL dimensions positively influenced, affected and correlated with People Capability Maturity Model (PCMM). But there was no difference in QWL among PCMM implemented and non-implemented organisations. The authors believe that the observed results can instigate the companies which have not implemented PCMM to prepare the employees psychologically to meet the demands and challenges which otherwise may risk a poor QWL program implementation.

Mosadeghrad [47] investigated the QWL of nurses in Iranian hospital as the nurses are subjected to high levels of stress due to the nature of their jobs. The main stressors are high physical strain, low degree of staffing, lower pay packages, lack of promotional opportunities, greater work load, which takes a heavy toll on them. He suggests that concepts like good and decent participation, treatment by the management, proper environment, increased income, and monetary benefits be given to the nurses to increase the QWL.

Coburn and Hall [48] studied the perception of QWL between four generations in the nursing workforce. Due to a different set of values held by each generation, the perception of QWL, psychological empowerment, and job satisfaction were better among the baby boomers suggesting a need to create a work environment by manager that is supportive of multiple generations of nurses. On the contrary, Han et al [49] observed that high quality initial training provided to the nurse produced better job satisfaction. Therefore, they have recommended that training be given priority to arrest high turnover rate among the nurses.

Further, Skinner et al [50] extended the work life challenges across the life course in healthcare professionals. She found a significant difference in the perception of work life balance at different stages of life. Such a pattern was also observed with respect to work demand and flexibility. However, the existing policies of the companies do not meet these demands which in turn lead to reduced work hours and increased turnover rates.

The studies on the public sector companies especially banking industry do not show high QWL [51]. Few reasons attributed to such poor QWL are inequitable reward system, which demotivate the better performing employees; the recruitment of overqualified personnel for rather routine job; frustration experienced due to lack of alternative job avenues; scarce chance of promotion; alienation from work and so on. Perhaps more autonomy, power and control and greater decentralization in order to recruit the right people for the right job, design of job description, and reward to employees based on performance may enhance the QWL in banks. On the contrary, staff of Air India (a public sector company) were more inclined to be satisfied with job with respect to physical and psychological conditions of work, such as family ties, job earned community respect, pride in organisation, reasonable working hours, rural background, etc., rather than to physical strain, friendship with colleagues, skills, risks of injury and good work location[52]. Among the bus drivers of Pune Municipal Corporation in a metropolitan city, QWL was related to working conditions, the quality of the buses driven, external conditions like pollution, and heavy work demands like the unruly and noisy commuters who are not cooperative [53].

Thus the philosophy and drive of QWL is not exactly aligned with the prevailing culture in the service industry, therefore, requires further study to understand and provide suggestions to tackle the challenges that arises from non-adoption of simple cost-effective methods that may improve the conditions. 


\section{Research Objectives}

The main objective of this study is to understand the constructs of QWL that has an impact on the overall satisfaction of the employees of the service sector industry.

\section{Research Methodology}

\section{a. Data Collection}

Survey method was used to collect data from different service sector organisations ranging from banks, hospitals, hotels, railways, insurance and IT. Random sampling technique was used to select the companies as well as the respondents. Around 171 employees of these organisations returned the filled-in questionnaires.

\section{b. Research Instruments}

The constructs used in the survey were modelled based on the constructs deduced by Walton [12].The items in the survey instrument were customized to address the targeted employees' needs and were basically established on the validated measures of work environment and organisational macroclimate of the service industry. Most of the items used in this study were constructed from previous research [54]-[56]. All the items in the questionnaire were marked on a seven-point Likert scale ranging from $1=$ Strongly Disagree to $7=$ Strongly Agree. A pilot study was conducted with50 respondents to ensure that the research instrument was reliable and valid. Those participated in the study were comfortable in using the questionnaire.

\section{c. Conceptual Model}

Literature on QWL dimensions have been shown to have a significant impact on the job satisfaction of the employees. The constructs used in this study were Commitment to work place, Job satisfaction, Opportunity to use and develop skills and capabilities and to growth, Training and development, Adequate and fair compensation, Safe and healthy working conditions, Work environment, and Social integration in the work organisation. These were tested for their relationship with over job satisfaction of employees. In this study, apositivist approach that comprised the deductive analytical techniques as established by past researchers was taken to maximise the advantages of the analysis[57]. Regression analysis was used to test the hypothesis.

\section{d. Data Analysis}

The descriptive statistics (percentages, mean scores, and standard deviations), and inferential statistics (Pearson's correlation coefficient, reliability and factorial analysis, and linear regression analysis) were analysed using SPSS v20.

\section{Results And Discussion}

A total of 171 employees from different service sector companies participated in the survey. There was not much difference found in the number of male $(55 \%)$ and female $(45 \%)$ respondents who participated in this study. Most of the respondents were between 20 and 45 years $(20-30$ years $=39 \% ; 31-45$ years $=40 \%)$. More than $75 \%$ of the respondents were married which supports our study's aim of finding the QWL among the married people as they were able to relate better to the constructs of the study. Almost equal number of the respondents was graduates and postgraduates (together $89 \%$ ) with $42 \%$ as junior staff and $46 \%$ as manager and above. About $57 \%$ had 2-10 years of overall experience in the industry and $57 \%$ of the respondents drawing salaries between Rs.11,000 and Rs.30,000. More than 71\% had been working in the present company for at least three years and those with more than 5 years of tenure were $49 \%$. The demographic details presented clearly justify the group of people selected for the study to give their opinion on QWL constructs used for the service sector companies. Table 1 depicts the demographic details.

Table 1. Demographic details of the respondents

\begin{tabular}{|l|c|c|}
\hline Gender & Frequency & Percentage \\
\hline Male & & \\
\hline Female & 94 & 54.97 \\
\hline Age & 77 & 45.03 \\
\hline $20-30$ yrs & & \\
\hline $31-45$ yrs & 66 & 38.6 \\
\hline$>46$ & 68 & 39.77 \\
\hline Marital Status & 37 & 21.64 \\
\hline Single & & \\
\hline Married & 38 & 22.22 \\
\hline Qualification & 133 & 77.78 \\
\hline Graduate & 77 & 45.03 \\
\hline Post Graduate & 76 & 44.44 \\
\hline
\end{tabular}




\begin{tabular}{|l|c|c|}
\hline Diploma & 18 & 10.53 \\
\hline Designation & & 11.7 \\
\hline Fresher & 20 & 42.11 \\
\hline Junior & 72 & 36.84 \\
\hline Manager & 63 & 9.36 \\
\hline Senior manager & 16 & \\
\hline Experience & & 12.28 \\
\hline$\leq 1$ yr & 62 & 36.26 \\
\hline $2-5$ yrs & 35 & 20.47 \\
\hline $6-10$ yrs & 53 & 30.99 \\
\hline$>10$ yrs & & 15.2 \\
\hline Income (monthly in Rs.) & 26 & 29.24 \\
\hline$\leq 10,000$ & 50 & 28.07 \\
\hline $11,000-20,000$ & 48 & 27.49 \\
\hline $21,000-30,000$ & 47 & \\
\hline$>30,000$ & & 9.94 \\
\hline $\begin{array}{l}\text { Tenure with current } \\
\text { organisation }\end{array}$ & 17 & 19.3 \\
\hline$\leq 1$ yr & 33 & 49.12 \\
\hline $1-2$ yrs & 37 & \\
\hline $3-5$ yrs & 84 & \\
\hline$>5$ yrs & & \\
\hline
\end{tabular}

Reliability analysis was conducted to test if the research conducted at a similar environment can produce the same result [58]. DeVellis [59] suggests a Cronbach's alpha of 0.7 as a reliable metric to be considered for high internal consistency. According to these standard measures, the Cronbach's alpha value for the current study ranged from 0.67 to 0.81 , which suggests the existence of internal consistency among the items of the constructs. Table 2 provides the Cornbach's alpha value of the eight dimensions of QWL selected for this study.

Table 2.Cronbach's alpha value for the identified constructs

\begin{tabular}{|l|c|}
\hline Dimensions & Cronbach's Alpha \\
\hline Commitment & 0.728 \\
\hline Job satisfaction & 0.710 \\
\hline Opportunity to use and develop skills and abilities & 0.710 \\
\hline Opportunity for growth & 0.670 \\
\hline Training and development & 0.717 \\
\hline Adequate and fair compensation & 0.785 \\
\hline Safe and healthy working conditions & 0.742 \\
\hline Social integration in the work organisation & 0.818 \\
\hline
\end{tabular}

KMO and Bartlett's Test of Sphericityestablishes the sampling adequacy, which is recommended to ascertain the item to variable ratio for the analysis that is being conducted. Though $\mathrm{KMO}$ value ranges from 0 to 1 , the accepted value is over 0.6. In this study, a value of 0.872 was obtained indicating the adequate sample size being considered. The Bartlett's Test of Sphericityrefers to the significance of the study, thus shows the validity and appropriateness of the responses collected to the QWL dimensions used in this study. A value less that 0.05 is admitted to be valid for Bartlett's Test of Sphericity (Table 3).

Table 3. KMO and Bartlett's Test used for sampling adequacy

\begin{tabular}{|c|c|c|}
\hline \multicolumn{2}{|c|}{ Kaiser-Meyer-Olkin Measure of Sampling Adequacy. } & $\begin{array}{r}.872 \\
5125.282\end{array}$ \\
\hline Bartlett's Test of Sphericity & df & 1225 \\
\hline & Sig. & .000 \\
\hline
\end{tabular}

Validity of the research instrument is essential to understand how well the concept is demarcated by the measures. The validity as defined by Hair, et al. [60]refers to "the degree to which a measure accurately represents what it is supposed to." Content validity, construct validity, and predictive validityare the three types of validity normally tested. Content validity, also known as the face validity, assesses the relation between the individual items and the concept it measures [61]. Construct validity has often been defined as the practical demonstration of a test to measure the construct it claims to be measuring. In this paper, content validity was reviewed through the literature, while construct validity is established through the factorial analysis. In this study, we have taken factors that had an Eigen value more than 1 with at least 0.4 as the loading. Table 4 illustrates the factor loadings obtained for the identified QWL constructs for the service sector. Factors that loaded below 0.4 were suppressed for better reading of the results. The results shows that eight factors were 
extracted with Eigen value more than $61 \%$ of the variability of the data. Among the eight factors that were extracted, Commitment to work place has been shown to be the most important factor that the employees consider as an important QWL dimension. Adequate and fair compensation contributed only $6.59 \%$ of the variance in the QWL dimensions suggesting that pay though important is not the main driving force of QWL. This was followed by Job satisfaction (5.53\%), Training and development (4.12\%), Safe and healthy working conditions (3.78\%), Skill utilization and opportunity for growth $(3.44 \%)$, Social integration in the work organisation (3.094\%), and Work environment (2.689\%).

Table 4. Factor loadings for QWL dimensions

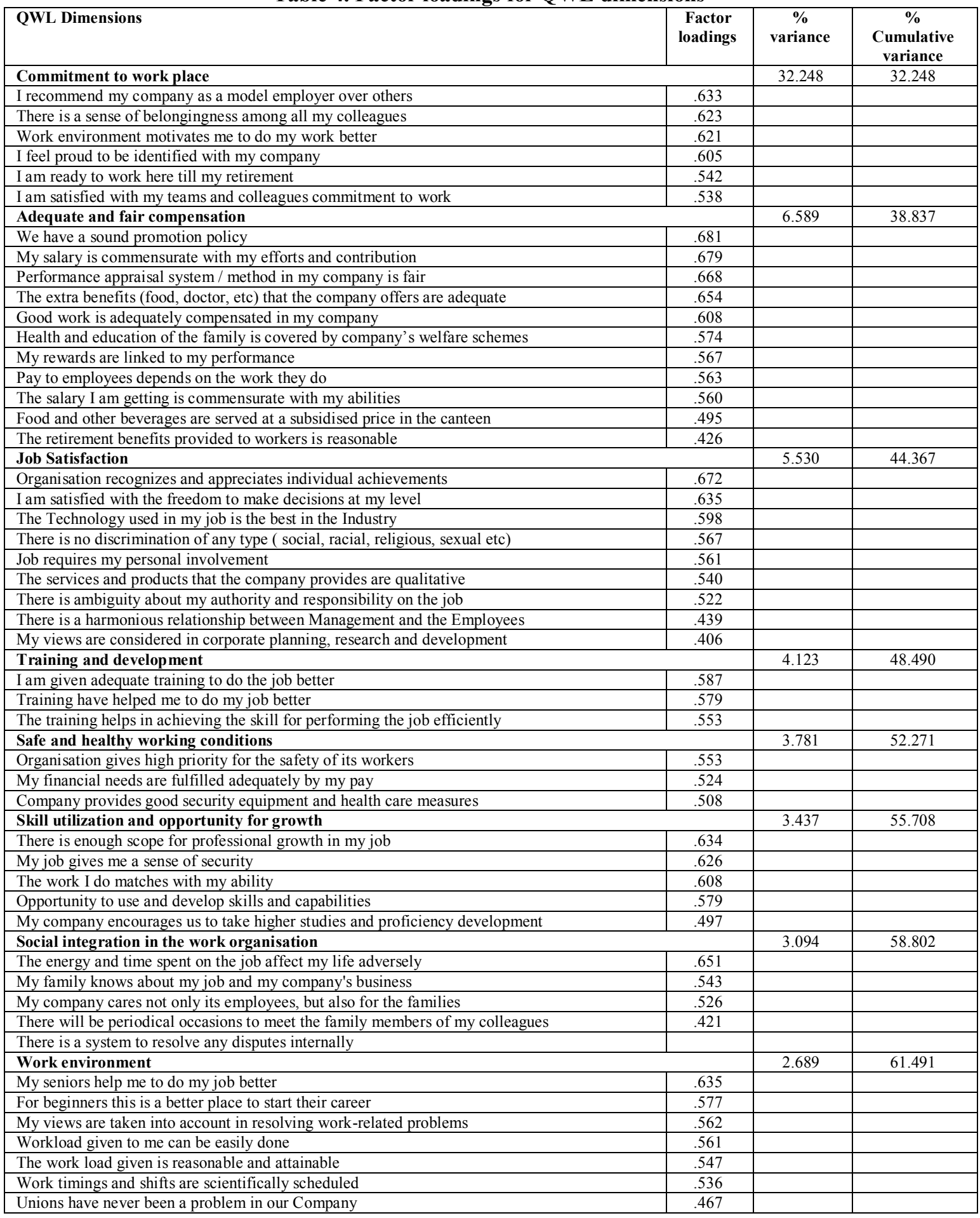




\section{Hypotheses Testing}

Based on the extracted factors, eight hypotheses were formulated to study the relationship between the QWL dimensions and the overall satisfaction of the service sector employees. The overall satisfaction an employee experiences in an organisation is taken as the dependent variable, while the eight QWL constructs were taken as the independent variables. The average of the items of the construct wastaken to conduct a series of linear regression, in order to obtain a best predictive model. The results of the regressionalso explain the variations in the dependent variable based on the variations in the independent variables. Hypotheses are accepted when standardised coefficient $(\beta)$ are significant, i.e., the p value should be less than 0.05 at $95 \%$ confidence level.

H1: Commitment to work place has a significant impact on the overall satisfaction with the work and the company.

Pearson correlation coefficient was conducted to test the association of the between the overall satisfaction of the employees with QWL dimensions (Table 5). The results of the study indicate a positive relationship between organisational commitment of the employees of service sector companies and overall satisfaction experienced by the employees $(r=0.679)$. Correlation was significant at 0.05 of alpha level. Alternatively, the results mean that as the organisational commitment of the employees increases, the overall satisfaction with the company will also increase, and vice versa. Further, coefficient of determination suggests that $46.1 \%$ of the overall satisfaction of the employees in the organisation can be organisational commitment of the employees $(\mathrm{F}=135.143)$ (Tables $6 \& 7)$. Previous studies have examined the relationship between organisational commitment and satisfaction, and reporteda positive relationship between the two [61]. Any deficiency in QWL will reduce the commitment of the employee to the organisation, which may lead to their intention to leave the organisation, shirking from responsibility and substandard service towards the customers [62]. This relationship of high commitment and high involvement in job was found to be positively correlated with positive customer service attitude [63]. Daud[64] also reported that different dimensions of QWL to have distinguishing effects on organisational commitments and quitting intentions. Organisational commitment was found to have a positive and direct relationship in terms of QWL dimensions in sectors like banking, food and educationindustry [65]-[67]. Moreover, studies have shown that women are more effectively committed to the organisation than are men [68]. In contrast, Aranya et al [69] and Marsden et al. [70] reported that men displayed a higher level of commitment than woman. Several studies have reported a positive correlation between human resource practices and organisational commitment [71].

Modern management of employees attempt to foster employee's commitment to the organisation by reinforcing employee loyalty as those committed are reported to perform better [72]. In line with those thoughtsMowday et al. [29] felt that committed employees are more aligned to the goals of the organisation and less likely to seek employment outside. Similarly, Baugh and Roberts [73] showed that strong levels of positive work were found in committed individuals. In contrast, those who were not committed recorded a weak level of positive outcome.

H2: Adequate and fair compensation has a significant impact on the overall satisfaction with the work and the company.

Adequate and fair compensation was positively related to the overall satisfaction of the employees with the organisation $(\mathrm{r}=0.559)$, and it could explain $31.2 \%$ of the variation in the overall satisfaction $(\mathrm{F}=71.142)$. This suggests that offering fair compensation is essential to retain the employees. When the competitors offer more compensation for the same job may trigger employees to join the competitor and result in high turnover rate. In a study conducted among IT professionals by Martinsons and Cheung [74] showed that poor promotion prospects and inadequate compensation lead to dissatisfaction in job prompt the employees to leave the organisation. Kleimen[75] in his study on bank employees too found that compensation could strongly influence the job satisfaction among the employees.

H3: Job satisfaction has a significant impact on the overall satisfaction with the work and the company.

Job satisfaction was also positively related $(r=0.488)$ to the overall satisfaction of the employees with the organisation $(\mathrm{r}=0.559)$. Job satisfaction could explain $23.8 \%$ of the variation in the overall satisfaction $(\mathrm{F}=49.271)$. Employee job satisfaction enhances the overall satisfaction among employees [76], which in turn is important for enhancing organisational and operational productivity. It is often observed that improving job satisfaction can increase the employee morale and organisational effectiveness [77]. Several extrinsic factors like benefits, pay, supervisory style, etc. arise as the determinants of QWL which play a vital for job satisfaction. Since QWL directly influences the human outcomes, it could significantly reduce absenteeism, grievances, and tendency to leave the organisation [78].

H4: Training and development has a significant impact on the overall satisfaction with the work and the company.

Increasing skills and capabilities through training programs is important to not only do the job better but also use it as a tool to motivate the employees. This study shows that Training and development was also 
positively related $(r=0.455)$ to the overall satisfaction of the employees with the organisation $(r=0.559$; $\mathrm{F}=41.276$ ). It could explain $20.7 \%$ of the variation in the overall satisfaction. It is clear from this study, employees look forward to training as a means to achieve their personal goals. Gupta and Sharma [79] have shown that employees of the BSNL company were motivated due to the training programs offered and the exams conducted for assessing the employees' capabilities and skills. Based on the results, they were often given training to enhance their skills. Esteves and Caetano [80] also observed that training and development to have one of the highest correlation with organisational commitment. Training and development practices contributed positively to the affective commitment, which in turn contributed to personal investment in career development.

H5: Safety and healthy working conditions of has a significant impact on the overall satisfaction with the work and the company.

One for the predictor for overall satisfaction of employees in the organisation is Safety and healthy working conditions. This was found to be positively related $(\mathrm{r}=0.463)$ to the overall satisfaction and could explain $21.4 \%$ of the variation in the overall satisfaction $(\mathrm{F}=43.131)$. Safety climate within an organisation refers to anenvironment of physical health and safety, which is observed to predict individual safety behaviour [81], industrial accidents and injury to physical health [82]. Thus, it relates to how the employees perceive the commitment of the management in terms of safety policy, procedures, and practicetowards employees' wellbeing. Therefore, organisations should have appropriate policy with regard to overtime, occupational hazards like over use of computers, phones, etc. among the service sector employees. The prevalent work practices in the service sector have several maladies (for example travelling, constant interaction with (irate) customers over phone or in person, etc.) attached to it. These need to be overcome with measures through imporving QWL dimensions.

H6: Skill utilization and opportunity for growth has a significant impact on the overall satisfaction with the work and the company.

Skill utilization and opportunity for growth was also positively related $(\mathrm{r}=0.598)$ to the overall satisfaction of the employees with the organisation $(\mathrm{r}=0.559 ; \mathrm{F}=87.927)$. It could explain $35.8 \%$ of the variation in the overall satisfaction. Offering career development for the employees is crucial as this study indicates that when they feel that when they have opportunity to grow, they tend to be satisfied with the company, which directly impact productivity of the employees. Further, employees also look for ways to put their skills to use. If the opportunity is denied, they become highly dissatisfied. They also expect the management to acknowledge their skills and utilize them in roles that would best suit the need of the employee. In addition, the employees prefer challenging outcome from their work as that would enable them to upgrade their knowledge, skills and capabilities constantly. On the other hand, factory-like monotonous work in a service industry would demotivate the employees from taking initiative for achieving organisation goal.In fact, a job, which is well accomplishedand challenging, can produce greater satisfaction than any monetary benefit can give as it can boost the self-confidence. Thus, an organisation, which does not take the initiative to keep its workforce motivated and challenging, may soon lose their best of their talent.

H7: Social integration in the work organisationhas a significant impact on the overall satisfaction with the work and the company.

Personal relationship within the organisation is an important dimension of QWL, where work and professional development are pursued within the framework of social integration. In this study, social integration in the work organisation was positively related $(\mathrm{r}=0.499)$ to the overall satisfaction of the employees with the organisation $(\mathrm{r}=0.559 ; \mathrm{F}=52.523)$. Around $25 \%$ of the variation in the overall satisfaction could be explained social integration factor. Social integration among the employees can be realized in an organisation by creating an environment, which is free from prejudice, supporting a sense of community and inter-personnel transparency among the workers at lower to middle levels and egalitarianism[83]. Employees in the service industry often work for long hours and on complex projects that keep them away from their home and other colleagues. The heterogeneous nature of the employees creates an unhealthy human relations and frictions among employees. Regular team meetings and departmental meetings may provide a healthy environment to voice their opinion about the challenges faced in the work. Therefore, it is the responsibility of the organisations to maintain an environment where employees can have get togethers, meet each other's families, and be part of the organisation. These exercises could boost the loyalty level among the employees.

H8: Work environment has a significant impact on the overall satisfaction with the work and the company.

Working conditions in an organisation can have positive impact on the health of the organisation. Work environment was also positively related $(r=0.560)$ to the overall satisfaction of the employees with the organisation $(\mathrm{r}=0.559)$. Working conditions could explain $31.4 \%$ of the variation in the overall satisfaction ( $F=72.259)$. Since an employees' QWL has direct impact on quality of life value, the QWL dimensions could be explained as physical and pscychological outcomes of the working condition, which affects the workers [76]. A 
conducive working environment motivates the employees to work towards organisational goal along with working for personal development.

Table 5: Correlation between the QWL dimensions and Overall satisfaction

\begin{tabular}{|c|c|c|c|c|c|c|c|c|c|}
\hline & $\begin{array}{c}\text { Overall } \\
\text { Satisfaction }\end{array}$ & Comit & FC & JS & TD & SH & SG & SI & WE \\
\hline $\begin{array}{l}\text { Overall } \\
\text { Satisfaction }\end{array}$ & 1 & & & & & & & & \\
\hline $\mathrm{FC}$ & $.559^{* *}$ & $.719^{* *}$ & 1 & & & & & & \\
\hline JS & $.488^{* *}$ & $.709^{* *}$ & $.779^{* *}$ & 1 & & & & & \\
\hline SG & $.598^{* *}$ & $.837^{* *}$ & $.741^{* *}$ & $.753^{* *}$ & $.637^{* *}$ & $.546^{* *}$ & 1 & & \\
\hline SI & $.499^{* *}$ & $.573^{* *}$ & $.665^{* *}$ & $.736^{* *}$ & $.478^{* *}$ & $.440^{* *}$ & $.578^{* *}$ & 1 & \\
\hline WE & $.560^{* *}$ & $.662^{* *}$ & $.792^{* *}$ & $.725^{* *}$ & $.536^{* *}$ & $.543^{* *}$ & $.650^{* *}$ & $.670^{* *}$ & 1 \\
\hline
\end{tabular}

**. Correlation is significant at the 0.01 level (2-tailed).

OS - Overall satisfaction; Comit - Commitment to work place; FC - Adequate and fair compensation; JS - Job satisfaction; TD - Training and development; SH - Safe and healthy working conditions; SG - Skill utilization and opportunity for growth; SI - Social integration in the work organisation; and WE - Work environment.

\begin{tabular}{|c|l|c|c|c|c|}
\hline Model & \multicolumn{1}{|c|}{ Independent Variable } & $\mathbf{R}$ & R Square & $\begin{array}{c}\text { Adjusted R } \\
\text { Square }\end{array}$ & $\begin{array}{c}\text { Std. Error of the } \\
\text { Estimate }\end{array}$ \\
\hline 1 & Commitment & .679 & .461 & 0.458 & 0.828555 \\
\hline 2 & Adequate and fair compensation & .559 & .312 & .308 & .93592 \\
\hline 3 & Job satisfaction & .488 & .238 & .233 & .98535 \\
\hline 4 & Training and development & .455 & .207 & .202 & 1.00493 \\
\hline 5 & Safe and healthy working conditions & .463 & .214 & .209 & 1.00028 \\
\hline 6 & Skill utilization and growth & .598 & .358 & .353 & .90460 \\
\hline 7 & Social Integration & .499 & .249 & .245 & .97771 \\
\hline 8 & Work environment & .560 & .314 & .309 & .93487 \\
\hline
\end{tabular}

Table 7: F values of the regression model

\begin{tabular}{|c|l|c|c|}
\hline Model & \multicolumn{1}{|c|}{ Independent Variable } & F value & Significance \\
\hline 1 & Commitment & 135.143 & 0.000 \\
\hline 2 & Adequate and fair compensation & 71.142 & 0.000 \\
\hline 3 & Job satisfaction & 49.271 & 0.000 \\
\hline 4 & Training and development & 41.276 & 0.000 \\
\hline 5 & Safe and healthy working conditions & 43.131 & 0.000 \\
\hline 6 & Skill utilization and growth & 87.927 & 0.000 \\
\hline 7 & Social Integration & 52.523 & 0.000 \\
\hline 8 & Work environment & 72.259 & 0.000 \\
\hline
\end{tabular}

\section{Conclusion}

Employees are the strength of an organisation and need to be treated with dignity and respect for their sincere and hard work. The employees have the burden of handling the responsibilities in their personal life as well as achieving the higher work expectations in their professional life. Managements should adopt several welfare measures and programs to satisfy the employees through various resources, activities and the participatory outcomes in a work place. A high quality of work life results in employee satisfaction and thus in high productivity. This study has shown that in order to keep the employees satisfied, the organisation must provide a conducive climate to enhance commitment, fair compensation, job satisfaction, safety and health, training and development, opportunity to develop skill and growth, social integration. It is suggested that organisations make performance appraisal transparent, conduct training programs that would enhance skills and capabilities of the employees. The employees who perform challenging jobs remain motivated and perform better. As the employees spend most of their time in the workplace, it is important that an effort be made to address the grievances and minor skirmishes among the employees. An organisation, which considers strategies and policies to create balance in work life, will possibly have a workforce that has increased productivity and increased penchant to work towards achieving organisation goals.

It should also be mentioned that the samples included in this comparative study are heterogeneous in terms of professions. While this heterogeneity has been intended in order to test the application of the measures in a broad spectrum of employed populations, it remains nevertheless unclear to what extent the reported psychometric properties hold true for other professional groups. 


\section{References}

[1]. ManishaPurohit, A comparative study of work life balance in various industrial sectors in Pune region. International Journal of Marketing, Financial Services and Management Research, 2(3), 2013.

[2]. S. Deery, R. Iverson, and J. Walsh, The effect of customer service encounters on job satisfaction and emotional exhaustion, in S. Deery and N. Kinnie (Eds) Call Centres and Human Resource Management: A Cross-National Perspective,(New York: Palgrave Macmillan, 2004), 201-221.

[3]. SiykaKovacheva and StanimirKabaivanov, Work-life balance of employees in Bulgarian service sector companies.

[4]. S. Hillmer, B.Hillmer, B. and G. McRoberts, The real costs of turnover: Lessons from a call centre. Human Resource Planning, 27(3), 2004, 34-41.

[5]. KhurramShahzad. UmerRehman, Ikramullah Shad, AsmaGul, Muhammad Amanullah Khan, Work-Life Policies and Job Stress as Determinants of Turnover Intentions of Customer Service Representatives in Pakistan, 2005.

[6]. G. Zhang, and G. Lee, The Moderation Effects of Perceptions of Organizational Politics on the Relationship between Work Stress and Turnover Intention: An Empirical Study about Civilian in Skeleton Government of China. iBusiness, 2, $2010,268-273$.

[7]. R. Cropanzano, D.E. Rupp, and Z.S. Byrne, The relationship of emotional exhaustion to work attitudes, job performance, and organizational citizenship behaviours.Journal of Applied Psychology, 88(1), 2003, 160-169.

[8]. M-F.Chen, C-P.Lin, and G-Y. Lien, Modeling job stress as a mediating role in predicting turnover intention. The Service Industries Journal, 2010, 1743-9507.

[9]. E.R.Kemery, K.W.Mossholder, and A.G.Bedeian, Role stress, physical symptomatology, and turnover intentions: A causal analysis of three alternative specifications.Journal of Occupational Behaviour, 8(1), 1987, 11-23.

[10]. K. Sandrick, Putting the emphasis on employees as an award.Winning employer,Baptist health care has distant memories of the workforce shortage, Trustee, 2003, 6-10.

[11]. R. E. Walton, Improving the quality of work life. Harvard Business Review. 1974.

[12]. J.-P. Martel, and G. Dupuis, Quality of work life: Theoretical and methodological problems, and presentation of a new model and measuring instrument. Social Indicators Research, 77, 2006, 333-368.

[13]. E. Mumford, The story of socio-technical design: reflections on its successes, failures and potential. Information Systems Journal, 16(4), 2006, 317-342.

[14]. L. L. Berry, The employee as customer. Journal of Retail Banking, 3(1), 1981, 33-39.

[15]. L.L.Berry, J.S., Hensel, and M.C. Burke, Improving retailer capability for effective consumerism response. Journal of Retailing, 52(3), 19763-14.

[16]. D. Holman, Employee well being in call centres. Human Resource Management Journal, 12(4), $200235-51$.

[17]. W. E. Greene,G.D. Walls, and L. J. Schrest, Internal marketing: The key to external marketing success. Journal of Services Marketing, 8(4), 19945-13.

[18]. J.W. Johnson, Linking employee perceptions of service climate to customer satisfaction. Personnel Psychology, 49(4) 1996, 831851 .

[19]. J. Griffith, Do satisfied employees satisfy customers? Support-services staff morale and satisfaction among public school administrators, students, and parents. 2001.

[20]. J. F. Von de Looi, and J. Bender, Not just money: quality of working life as employment strategy. Health Manpower, 21(3), 1995, 27-33.

[21]. P.A.Dabholkar, D.I. Thorpe, and J.O. Rentz, A measure of service quality for retail stores: Scale development and validation. Journal of the Academy of Marketing Science, 24(1), 1996, 3-16.

[22]. S. S.Tzafrir, andA. B. HRM practices and perceived service quality: The role of trust as a mediator. Research and Practice in Human Resource Management, 15(2), 2007, 1-20.

[23]. M. R.Testa, and M. G. Ehrhart, Service leader interaction behaviors: Comparing employee and manager perspectives. Group and Organization Management, 30(5), 2005, 456-486.

[24]. R. Hodson, and V. J. Roscigno, Organizational success and worker dignity: Complementary or contradictory? American Journal of Sociology, 110(3), 2004, 672-708.

[25]. J. L. Suttle, Improving life at work problems and prospects, in J. R. Hackman and J. L. Suttl(Eds.) Improving life at work: Behavioral science approaches to organizational change, 1977, 1-29.

[26]. M. H.Yoon, and J. Suh, Organizational citizenship behaviors and service quality as external effectiveness of contact employees. Journal of Business Research, 56(8), 2003, 597-611.

[27]. P.Gropel, and J. Kuhl, Work-Life Balance and Subjective Well-Being: The Mediating Role of Need Fulfilment. British Journal of Psychology, 100(2), 2009, 365-375.

[28]. B.Edvardsson, and B. Gustavsson, Quality in the work environment: a prerequisite for success in new service development. Managing Service Quality, 13(2), 2003, 148-163.

[29]. R. T.Mowday, R. Steers, and L. Porter, The Measurement of Organizational Commitment. Journal of Vocational Behavior, 14, 1979, 224-247.

[30]. C. W. Muelluer, E. M.Boyer, J. L.Price, and R. D. Iverson, Employee Attachment and Noncoercive Conditions of work: The Case of Dental Hygienists. Work and Occupations, 21(2), 1994, 179-212.

[31]. L.Jauch, W. F., Glueck, and R. N. Osborn, Organizational Loyalty, Professional. 1978.

[32]. M. M.Hossain, and M. T. Islam, QWL and job satisfaction of Nurses in Government Hospitals in Bangaladesh. Indian Journal of Industrial Relations, 34(3), 1999, 33-34.

[33]. S.Hutchinson, J. Purcell, and N. Kinnie, The Challenge of the Call Centre. Human Resource Management International Digest, 8(5), 2000, 4-7.

[34]. S. Deery, and N. Kinnie, Call centres and beyond: A thematic evaluation. Human Resource Management Journal, 12(4), 2002, 314.

[35]. J., Paul, and U. Huws, How Can We Help? Good practice in call centre employment. Analytical Social and Economic Research Ltd. (2002).

[36]. M. Houlihan, Tensions and variations in call centre management strategies. Human Resources Management Journal, 12(4), 2002, 67-86.

[37]. Hannif, Zeenobiyah, (2008), " Call Centers and the Quality of Work Life: Towards a Research Agenda", Journal of Industrial Relations, 50(2) 271-284.

[38]. D. R. Saklani, Quality of work life in the Indian Context: An Empirical Investigation. Decisions, 31(2), 2004, 101-135.

[39]. B. A.Brooks, and M. A. Anderson, Defining quality of nursing work life. Nursing Economics, 23(6), 2005, 319-326. 
[40]. N. Dhadda, A study of the relationship of role, job involvement and personality types in aviation and railway officials. Jaipur: M.Phil. Dissertation, University of Rajasthan, 1990.

[41]. J. Venkatachalam, K. S.Reddy, and S. Samiullah, Effect of jab level and the organization's identity on job involvement and job satisfaction: A study of different organizations. Management and labour studies, 23(3), 1998.

[42]. V. Manickavasagam, and S. Sumathi,.A study of job satisfaction among the employees of Dalmiamagnesite corporation, Salem.Manpower Journal. 36 (3), 2000, 95-99.

[43]. B. P. Ramesh, Cyber Coolies in BPO: Insecurities and Vulnerability of Non-standard Work. Economic and Political Weekly, 39(5), 2004, $492-497$.

[44]. Wickramasinghe Vathsala. Work-related Dimensions and Job Stress: The Moderating Effect of Coping Strategies, research article. Published online in Wiley InterScience. 2010.

[45]. M. M. Juliet, Quality of work life in relation to people capability maturity model in it and ites organizations, Other thesis, Christ University, 2012.

[46]. A. M. Mosadeghrad, Quality of working life and turnover intentions: implications for nursing management. International Journal of Research in Nursing, 4(2), 2013, 47-54.

[47]. A. S., Coburn, and S. J. Hall, Generational differences in nurses' characteristics, job satisfaction, quality of work life, and psychological empowerment. Journal of Hospital Administration, 3(5), 2014, 124-134.

[48]. K., Han, T., M., A., Storr, C. L., Lerner, N., andK. G. Meg Johantgen, Associations between state regulations, training length, perceived quality and job satisfaction among certified nursing assistants: Cross-sectional secondary data analysis. International Journal of Nursing Studies, 2014.

[49]. N. Skinner, J.Elton, J. Auer, and B. Pocock, Understanding and managing work-life interaction across the life course: a qualitative study. Asia Pacific Journal of Human Resources, 52(1), 2014, 93-109.

[50]. Uma Sekaran. Journal of Applied Social Psychology, 31(8), 1985, 1627-1658.

[51]. O. N. Ganguli, and J. S. Joseph, Quality of Working Life: Work prospects and aspirations of young workers in Air India, Bombay, Central Labour Institute. (1976).

[52]. R. L. Dhar, Quality of work life: a study of municipal corporation bus drivers. Uluslararası Sosyal Araştırmalar Dergisi The Journal of International Social Research, 1(5), 2008, 251- 273.

[53]. J.R., Hackman, and G.R., Oldham, Work Redesign. (Addison-Wesley, Reading, M.A, 1980)

[54]. G. M., Spreitzer,Social structural characteristics of psychological empowerment,Academy of Management Journal, 39, 1996, 483504.

[55]. R. R, Callister, The Impact of Gender and Department Climate on Job Satisfaction and Intentions to Quit for Faculty in Science and Engineering Fields The Journal of Technology Transfer31(3), 2006, pages 367-375.

[56]. M.Easterby-Smith, R. Thorpe, and A. Lowe, Management research: An introduction (SAGE Publications, London, 2002).

[57]. J. Ritchie, and J. Lewis, (Eds.), Qualitative research practice: A guide for social science students and researchers. (London, Sage, 2003).

[58]. R., DeVellis, Scale development: theory and applications. Sage Publications, Thousand Oaks, (2003).

[59]. J., Hair, W., Black, B., Babin, R., Anderson, and R. Tatham, Multivariate Data Analysis. $6^{\text {th }}$ ed. New Jersey: Pearson Education, Inc. (2007).

[60]. N. Malhotra, Marketing Research: an applied orientation, $6^{\text {th }}$ ed. Boston: Pearson Education. 2010.

[61]. S. P., Brown, and R. A. Peterson,.The effect of effort on sales performance and job satisfaction. Journal of Marketing, 58, 1994, 7080.

[62]. L., Porter, R, Steers, R., Mowday, P. Boulian,.Organizational commitment, job satisfaction, and turnover among psychiatric technicians. Journal of Applied Psychology, 59, 1974, 603-609.

[63]. J. C., Anderson, M., Rungtusanatham, and R. G. Schroeder,.A theory ofquality management underlying the Deming managementmethod.Academy ofMariagementReview, 19, 1994, 472-509.

[64]. N., Daud,.Investigating the relationship between quality of work life and organizational commitment amongst employees in Malaysian firms. Int. J. Bus. Manage., 5, 2010, 75-82.

[65]. M. Anand, and D. Arora, 2009.Burnout, life satisfaction and quality of life among executives of multi national companies. J. Indian Acad. Applied Psychol., 35: 159-164.

[66]. M., M. Arandjelovic, Nikolic and S. Stamenkovic,.Relationship between burnout, quality of life and work ability index-directions in prevention. Sci. World J., 10, 2010, 766-777.

[67]. K.R., Niaand M. MalekiA Study of the Relationship between Quality of Work Life and Organizational Commitment International Journal of Research in Organizational Behavior and Human Resource Management, 1(4), 2013, pp. 83-94.

[68]. R. T., Mowday, L. W., Porter, and R. M. Steers, Employee Organization Linkages: The Psychology of Commitment, Absenteeism and Turnover. San Diego, CA: Academic Press. 1982.

[69]. N., Aranya, T., Kushnir, and A. Valency, Organization Commitment in a Male Dominated Profession. Human Relations, 39, 1986, 433-450.

[70]. P. V., Marsden, A. L., Kalleberg, and C. R. Cook, Gender Differences in Organizational Commitment: Influence of Work Positions and Family Roles. Work and Occupations, 20, 1993, 368- 390.

[71]. C. M., Lau, and H. Y. Ngo, One Country Many Cultures: Organizational Cultures of Firms of Different Country Origins. 1996.

[72]. L.R., Jauch, W.F. Glueck, and R.N., Osborn, (), Organizational Loyalty, Professional. 1978.

[73]. S. G., Baugh, and R. M. Roberts, Professional and organizational commitment among engineers: Conflicting or complementing? IEEE Transactions of Engineering Management, 41, 1994, 108-114.

[74]. M.G., Martinsons, and C., Cheung,. "The Impact of Emerging Practices on IS Specialists: Perceptions, Attitude and Role Changes in Hong Kong".Information and Management, 30, 2001, pp.167-183.

[75]. L. S. Kleiman, () Human Resources Management: A Managerial Tool for Competitive Advantage (2ndEdn.). biztantra: New delhi. 2005

[76]. J. Ruzevicius, Working Life Quality and Its Measurement.Forum Ware International, 2, 2007.

[77]. M. d. hanlon, and d. L. Gladstein, () Improving the Quality of Work Life in hospitals: A Case Study, Hospital Health Service Administration, 29(5), 1984, 94-107.

[78]. M. K., Newaz, T. Ali, and I. Akhter, () Employee Perception Regarding Turnover decision- In Context of bangladesh banking Sector, BRAC University Journal, 4(2), 2007, 67-74.

[79]. M., Gupta, And P. Sharma, Factor Credentials Boosting Quality Of Work Life Of Bsnl Employees In Jammu Region. Apjrbm, 2(1), 2011, 79-89.

[80]. T., Esteves, and A. Caetano, Human Resource Management Practices and Organizational Results, 1996, 239-249. 
[81]. I. R., Coyle, S. D., Sleeman, and N. Adams, Safety climate. Journal of Safety Research, 26, 1995,247-254.

[82]. A., Neal, and M. A. Griffin, A study of the lagged relationships among safety climate, safety motivation, safety behavior, and accidents at the individual and group levels.Journal of Applied Psychology, 91, 2006, 946-953.

[83]. P. Rathamani and RameshwariRamchandra, A Study on Quality of Work Life of Employees in Textile Industry - Sipcot, Perundurai. IOSR Journal of Business and Management (IOSR-JBM), 8(3), 2013, 54-59. 